\title{
Analisis Citra Landsat ETM+ untuk Kajian Awal Penentuan Daerah Potensi Panas Bumi di Gunung Lamongan, Tiris, Probolinggo
}

\author{
Widya Utama, ${ }^{*}$ S Riski, AS Bahri, dan DD Warnana \\ Prodi Geofisika, Jurusan Fisika-FMIPA, \\ Institut Teknologi Sepuluh Nopember \\ Kampus ITS Sukolilo, Surabaya 61111
}

\begin{abstract}
Intisari
Dalam peneltian, citra Landsat ETM+ dipakai untuk mengidentifikasi geomorfologi dan distribusi temperatur permukaan bumi untuk mengenali daerah prospek potensi panas bumi di wilayah Gunung Lamongan, Tiris, Kabupaten Probolinggo. Koreksi yang dilakukan dalam pengolahan citra dilakukan secara standar. Interpretasi geomorfologi menunjukan adanya sesar dominan pada arah barat laut - tenggara. Interpretasi suhu permukaan menunjukkan manifestasi sumber panas bumi di permukaan di dekat sistem sesar. Hal ini menunjukkan bahwa gunung Lamongan merupakan daerah potensi energi panas bumi yang perlu dikaji lebih lanjut untuk mendeliniasi daerah reservoir di bawah permukaan melalui kajian geologi, geokimia dan geofisika.
\end{abstract}

KATA KUNCI: panas bumi, citra Landsat 7 ETM+, geomorfologi, temperatur bumi.

\section{PENDAHULUAN}

Penelitian ini merupakan aplikasi teknologi penginderaan jauh dalam kajian awal untuk identifikasi daerah prospek panas bumi di daerah Tiris, Kabupaten Probolinggo, Provinsi Jawa Timur. Teknologi satelit yang dipakai adalah satelit Landsat 7 ETM+ (Enhanced Thematic Mapper Plus). Data citra satelit Landsat 7 ETM+ digunakan karena kemudahannya dalam mendapatkan data dan proses pengolahannya, serta mencakup area yang luas. Data citra satelit ini dapat diunduh dengan mudah secara gratis. Software pengolahan citra yang digunakan adalah ILWIS 3.7, bersifat open source.

Permasalahan yang akan dibahas dalam kajian ini adalah pemetaan geomorfologi dan distribusi temperatur permukaan tanah daerah Gunung Lamongan, Tiris, Kabupaten Probolinggo dan sekitarnya melalui analisa citra satelit Landsat 7 ETM+. Tujuan kajian ini adalah memetakan geomorfologi dan temperatur permukaan tanah daerah tersebut di atas.

Dapat diharapkan bahwa kajian ini akan bermanfaat untuk perencanaan rinci survei geologi yang akan bermuara pada upaya deliniasi wilayah prospek potensi geothermal di Tiris, Kabupaten Probolinggo. Dengan demikian, eksplorasi potensi panas bumi dapat dilakukan tahap demi tahap secara efisien dan berkelanjutan.

\section{TINJAUAN PUSTAKA}

Data penginderaan jauh yang dipakai adalah citra satelit hasil perekaman energi cahaya pada spektrum tampak dan

*E-MAIL: widya@physics.its.ac.id

(C) Jurusan Fisika FMIPA ITS

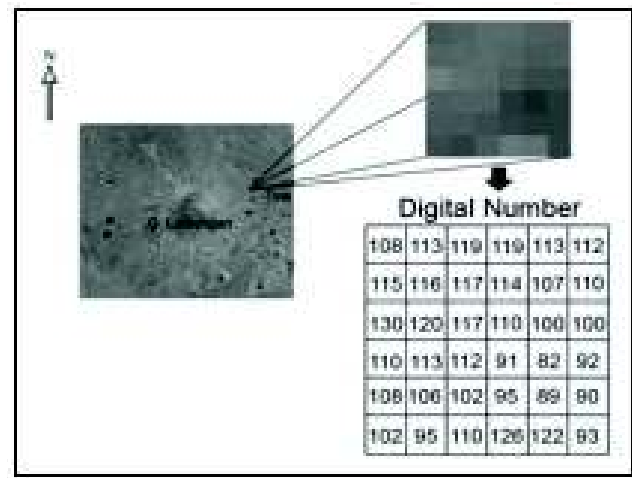

Gambar 1: Komposisi nomor piksel dan angka tingkat keabuan (gray-scale) piksel dari citra satelit

spektrum ultraviolet dan inframerah. Melalui karakterisasi tingkat energi serapan, pantulan dan transmisi tersebut, maka obyek pada permukaan bumi dapat dikenali.

Landsat 7 ETM+ yang terdiri dari 8 band, dirancang secara spesifik untuk memperoleh data sumber daya bumi. Satelit ini mengorbit dengan ketinggian $705 \mathrm{~km}$, berulang dalam 16 hari. Citra satelit ini memiliki resolusi 30 meter, dengan luasan mencakup $185 \mathrm{~km}^{2}$. Secara radiometrik, sensor ETM+ memiliki 256 digital number (DN, nomor digital, 8 bit) [1], [2].

Foto hitam putih pada Gambar 2 menunjukkan daerah sekitar Tiris, Probolinggo. Foto tersebut sesungguhnya tersusun atas piksel. Setiap piksel ditunjukkan oleh nomer digitalnya dan memiliki nilai kecerahan tertentu. Ukuran piksel sesuai dengan daya resolusi citra. 




Gambar 2: (a) Citra satelit sebelum koreksi radiometrik dan (b) setelah koreksi radiometrik

\section{Koreksi Radiometrik dan Geometrik}

Koreksi radiometrik dilakukan untuk meningkatkan kontras (enhancement) setiap piksel dari citra. Kontras diperlukan agar objek yang terekam mudah diinterpretasi atau dianalisis untuk memperoleh data/informasi yang benar sesuai dengan keadaan lapangan, lihat Gambar 2. Koreksi geometrik dilakukan untuk memposisikan citra terhadap koordinat obyek di permukaan bumi, karena efek perputaran bumi, arah pergerakan satelit dan lengkung permukaan bumi [3].

\section{Konversi Temperatur}

Pada setiap temperaturnya, sebuah benda akan memancarkan panjang gelombang elektromagnetik yang berbeda, yang dinyatakan dengan Hukum Pergeseran Wien. Penentuan temperatur sebuah massa dapat diketahui dari pengukuran pancaran gelombang elektromagnetiknya. Untuk mengenali temperatur obyek diperlukan langkah konversi temperatur Konversi ini bertujuan untuk menghilangkan pengaruh atmosfer terhadap nilai temperatur absolut [4], mengingat obyek sebenarnya ada di permukaan tanah sedangkan sensor berada di luar angkasa. Persamaan yang digunakan untuk mengkonversi digital number (DN) ke top of atmosphere (TOA) radiance adalah sebagai berikut [4]:

$$
\begin{aligned}
L_{\lambda} & =\left(\frac{L_{\max , \lambda}-L_{\min , \lambda}}{Q_{\text {calmax }}-Q_{\text {calmin }}}\right)\left(D N-Q_{\text {calmin }}\right) \\
& +L_{\min , \lambda}
\end{aligned}
$$

dengan $\mathrm{L}_{\lambda}$ adalah TOA radiance pada sensor $\left(\mathrm{W} / \mathrm{m}^{2} \mathrm{sr}\right.$ $\mu \mathrm{m}), \mathrm{L}_{\max }$ adalah TOA radiance terskala terhadap $\mathrm{Q}_{\text {calmax }}$, $\mathrm{L}_{\text {min }}$ adalah TOA radiance terskala terhadap $\mathrm{Q}_{\text {calmin }}$, $\mathrm{Q}_{\text {calmax }} / \mathrm{Q}_{\text {calmin }}$ adalah nilai pixel maximum / minimum.

Konversi top of atmosphere (TOA) radiance ke radiance yang meninggalkan permukaan menggunakan persamaan berikut [4]:

$$
L_{T}=\frac{L_{\lambda}-L_{\mu}-\tau(1-\epsilon) L_{d}}{\tau \epsilon}
$$

dengan $\mathrm{L}_{T}$ : radiance dari kinetik blackbody obyek pada temperatur $\mathrm{T}, \mathrm{L}_{\mu}$ : upwelling (radiance di atmosfer) $\left(\mathrm{W} / \mathrm{m}^{2} \mathrm{sr}\right.$ $\mu \mathrm{m}), \mathrm{L}_{d}$ : downwelling (radiance di angkasa) $\left(\mathrm{W} / \mathrm{m}^{2} \mathrm{sr} \mu \mathrm{m}\right)$, $\tau:$ transmisivitas atmosfer dan $\epsilon$ : emisivitas obyek.
Sensor temperatur mengasumsikan bahwa permukaan bumi adalah black body (emisivitas 1), dengan melibatkan konstanta kalibrasi sensor. Persamaan konversi dari sensor spectal radiance kedalam temperatur adalah [2]:

$$
T=\frac{K_{2}}{\ln \left(\frac{K_{1}}{L_{T}}+1\right)}
$$

dengan $\mathrm{K}_{1} ; \mathrm{K}_{2}$ adalah konstanta $\left(666.09 ; 1282.71\left(\mathrm{~W} / \mathrm{m}^{2} \mathrm{sr}\right.\right.$ $\mu \mathrm{m})), \mathrm{L}_{T}$ : spectral radiance pada sensor $\left(\mathrm{W} / \mathrm{m}^{2} \mathrm{sr} \mu \mathrm{m}\right)$.

\section{Peningkatan Kontras Citra}

Salah satu bentuk filter yang digunakan untuk mendeteksi tepi sebuah obyek di permukaan adalah filter konvolusi Laplace. Filter ini merupakan filter high pass. Pendekatan bentuk matrik dari filter digital ini terhadap operator Laplace adalah, untuk 2 dimensi:

$\begin{array}{ccc}1 & 1 & 1 \\ 1 & -8 & 1 \\ 1 & 1 & 1\end{array}$

Filter ini akan meningkatkan kontras sebuah piksel dari nilai keabuan piksel di sekitarnya, dengan faktor gain 1. Filter ini memiliki kemampuan untuk meningkatkan kontras yang berefek mempertegas batas atau tepi sebuah obyek, dalam hal ini berkorelasi dengan fenomena geologi dari kondisi sekitarnya di permukaan bumi [5].

\section{HASIL DAN ANALISIS}

Karakteristik data citra satelit yang digunakan dalam tugas akhir ini yaitu Landsat 7 ETM+, koordinat tipe UTM dengan datum WGS84, direkam pada tanggal 19/05/2002 pukul 09:24:28.41 WIB dengan tipe data raster. Data citra Landsat 7 yang digunakan berada pada tingkat satu yang artinya data citra tersebut telah memperoleh koreksi radiometrik dan geometrik.

\section{Citra Geomorfologi}

Data yang digunakan untuk pemetaan geomorfologi ini adalah band 4 (0,772-0,898 $\mathrm{m})$, yang memiliki range pa-ling lebar di antara band reflektif lainnya. Data yang diolah berupa data single band sehingga tampilan berformat gray-scale. Penerapan filter konvolusi Laplace pada data band 4 untuk mempertajam tepi suatu objek, misalnya sesar (fault), jalan, sungai dan sebagainya. Dalam interpretasinya, kelurusan obyek ditunjukkan oleh kelurusan susunan piksel terutama yang berwarna putih hingga abu-abu. Hasilnya ditunjukkan pada Gambar 3, yang secara visual menampakkan korelasi susunan piksel dengan obyek yang berasosiasi tepi sungai, jalan, stuktur geologi lainnya, untuk daerah Tiris dan sekitarnya. 


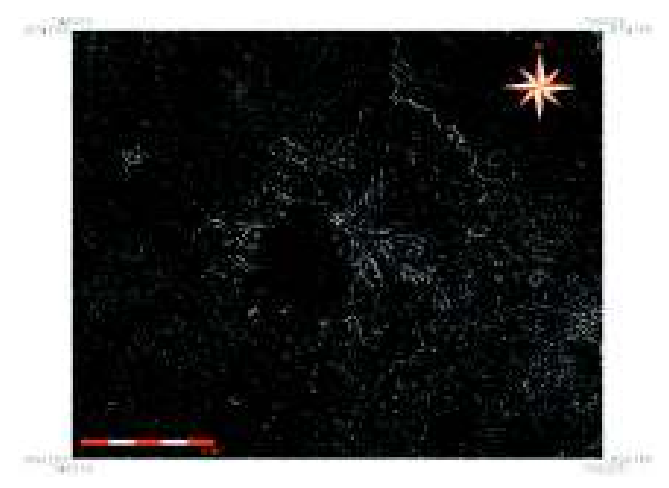

Gambar 3: Citra geomorfologi hasil pengolahan data band 4 untuk daerah Tiris, Probolinggo dan sekitarnya

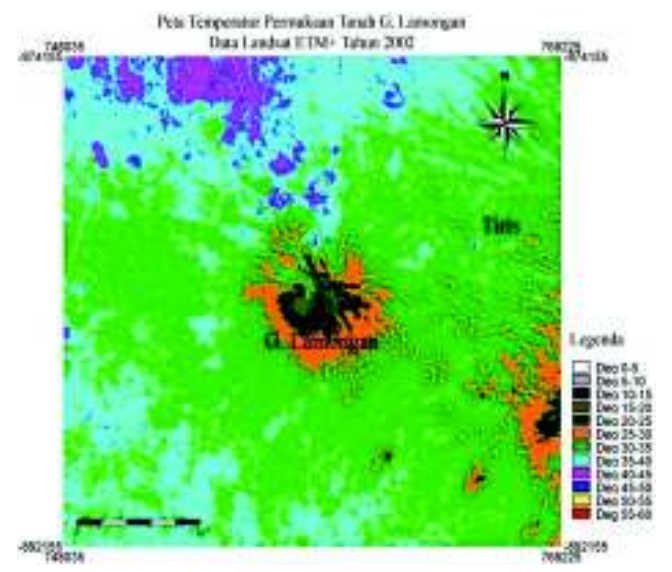

Gambar 4: Citra temperatur permukaan tanah daerah Tiris Probolinggo dan sekitarnya

\section{Citra Temperatur Permukaan}

Data yang digunakan untuk memetakan temperatur permukaan tanah adalah band $61(10,31-12,36 \mu \mathrm{m})$, jendela atmosfer gelombang elektromagnetik inframerah termal. Dengan asumsi bahwa permukaan bumi adalah black body dengan emisivitas 1, puncak pancaran bumi yang suhu permukaannya rata-rata terjadi pada suhu $300 \mathrm{~K}$ dengan panjang gelombang $10 \mu \mathrm{m}$. Sensor satelit Landsat 7 ETM+ bersifat pasif, dengan sumber utama energi yang terekam adalah sinar matahari. Data yang terekam dapat dipengaruhi oleh tutupan awan dan waktu perekaman siang atau malam.

Hasil koreksi atmosfer dan koversi temperatur dari TOA radiance hingga ke temperatur permukaan tanah dari data band 61, ditunjukkan pada Gambar 4 berikut ini untuk lokasi Tiris, Probolinggo dan sekitarnya. Nilai temperatur permukaan tanah yang didapat pada pengolahan ini memiliki range $114,9^{\circ} \mathrm{C}$ hingga $63,6^{\circ} \mathrm{C}$. Temperatur minus ini biasanya berasosiasi dengan temperatur awan, sementara temperature tinggi dapat berasosiasi dengan fenomena vulkanik. Klaster temperatur dengan interval $5^{\circ} \mathrm{C}$ untuk jangkauan mulai dari $0^{\circ} \mathrm{C}$ hingga $60^{\circ} \mathrm{C}$ dibuat untuk memudahkan interpretasi.

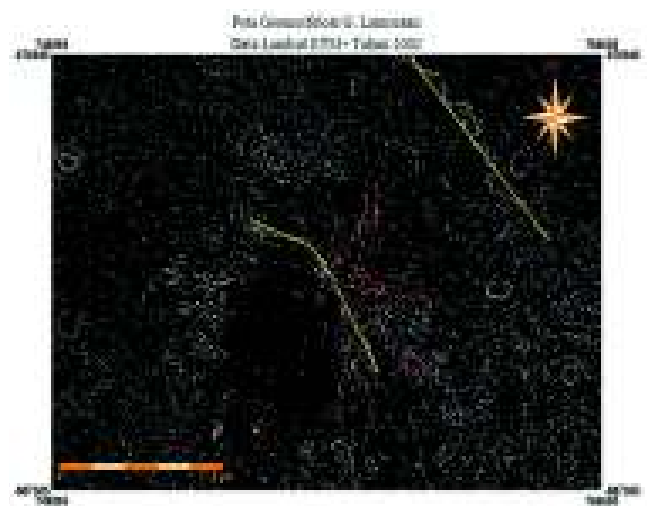

Gambar 5: Identifikasi kelurusan struktur pada geomorfologi daerah Tiris Probolinggo.

\section{Interpretasi Geomorfologi}

Analisa geomorfologi ini dilakukan dengan melihat kecenderungan pola kelurusan obyek pada Gambar 3. Utamanya analisa ini ditujukan untuk menandai daerah-daerah yang dipengaruhi oleh sesar. Keseragaman arah obyek akan menunjukkan pola sesar pada daerah kajian. Keberadaan sungai juga bisa berasosiasi dengan sesar.

Dari Gambar 5 dapat ditunjukkan bahwa arah sesar dominan pada arah Barat Laut - Tenggara, ditandai oleh kelurusan yang panjang (perhatikan garis kuning). Dari gambar tersebut terlihat bahwa ada 2 patahan dominan yaitu: pada tubuh $\mathrm{Gu}-$ nung Lamongan dan di daerah Tiris yang berasosiasi dengan Sungai Pekalen.

Pada zona-zona lemah, di bawah permukaan bumi terdapat banyak rekahan apriori menjadi merupakan sebuah reservoir panas bumi. Fluida yang terus dipanaskan oleh sumber panas (geothermal heat source) akan mengalir dan berkumpul dalam reservoir panas bumi. Dengan demikian adanya patahan di daerah vulkanisme tua dapat dijadikan sebuah indikator kuat sebagai daerah prospek yang memiliki potensi energi panas bumi.

\section{Interpretasi Temperatur Permukaan Tanah}

Menentukan daerah prospek panas bumi harus memperhatikan pula sebaran temperatur permukaan tanahnya selain karateristik geomorfologi. Selain itu, sesar di permukaan bumi juga memungkinkan adanya manisfestasi panas bumi, akibat keluarnya air panas dari reservoir melalui bidang sesar. Manisfestasi mata air panas bisa berasosiasi sebagai titik up flow maupun out flow, tergantung dari karakteristik aliran yang bisa diketahui dari analisa kimia air panas.

Analisa geomorfologi membantu untuk mendapatkan lokasi patahan. Pada daerah patahan, potensi keberadaan manifestasi sumber air panas sangat besar. Manifestasi ini tentu dicirikan oleh radiasi temperatur yang lebih tinggi dari sekitarnya. Perhatikan daerah patahan (garis kuning) pada Gambar 5 dan bandingkan dengan Gambar 6 pada daerah A 


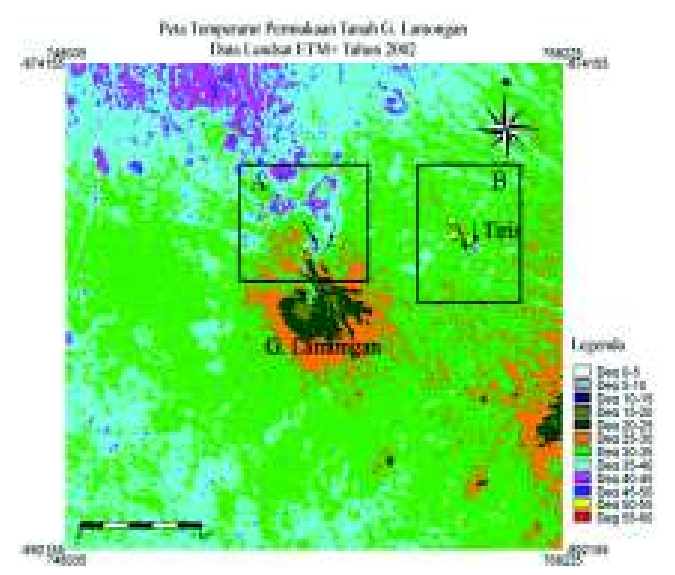

Gambar 6: Citra sebaran panas permukaan bumi daerah Tiris, Probolinggo dan sekitarnya; daerah A dan B adalah daerah titik panas bumi yang berasosiasi dengan potensi energi panas bumi.

dan B. Perhatikan daerah A, terdapat pancaran panas yang tinggi yang sangat lokal, lihat tanda panah. Demikian pula di daerah Tiris (daerah B) terdapat pancaran temperatur tinggi yang sangat lokal, ditunjukkan oleh tanda panah. Dengan demikian dapat diinterpretasikan bahwa di daerah A dan B kemungkinan besar juga memiliki manifestasi panas bumi.

Titik-titik temperatur tinggi yang tersebar merata dan sporadis di sebelah utara Gunung Lamongan berasosiasi dengan aktifitas manusia, karena daerah tersebut merupakan daerah pemukiman padat penduduk; disamping itu merupakan daerah dataran rendah yang tidak memiliki gejala vulkanik di permukaan bumi.

Hasil interpretasi sesuai dengan kondisi di lapangan; di daerah B ditemukan lebih dari 4 titik manifestasi panas bumi. Lokasi manifestasi ditunjukkan oleh titik-titik berwarna kuning (lihat Gambar 5). Sejauh ini, manisfestasi tersebut dipakai sebagai salah satu obyek pariwisata lokal. Uji lapangan di daerah A tidak dilakukan, karena medan terlampau sulit un- tuk dijangkau dengan sarana dan prasarana yang ada hingga saat ini.

\section{SIMPULAN}

Simpulan yang diperoleh dari aplikasi citra dan analisa data satelit Landsat 7 ETM+ adalah sebagai berikut :

1. Kondisi geomorfologi dan sebaran temperatur tanah dan keberadaan titik-titik manisfestasi potensi panas bumi dapat dipakai untuk mengidentifikasi lokasi survei lanjutan untuk kemudian dalam penentuanbatasan daerah prospek panas bumi.

2. Pada daerah Gunung Lamongan dan sekitarnya terdapat 2 sesar dominan yang berarah Barat Laut - Tenggara. Manifestasi panas bumi juga muncul ke permukaan melalui jalur sesar yang ada tersebut. Sesar ini menunjukkan bahwa daerah Tiris mempunyai prospek energi panas bumi. Dalam tindak lanjut, kegiatan survei di lapangan untuk mendeliniasi daerah potensi secara jelas diperlukan survei geologi dan geokimia dan geofisika pada daerah tertentu, khususnya di daerah sekitar patahan dan mengarah wilayah Gunung Lamongan.

\section{Ucapan Terima Kasih}

Penelitian dibiayai oleh dan merupakan bagian dari kerjasama antara ITS dan Dinas ESDM Provinsi Jawa Timur. Penulis menyampaikan terimakasih kepada tim peneliti dari Lab. Vulkanologi dan Geothermal ITB dan GFZ Jerman atas diskusi yang sangat instens kesempatan menggunakan peralatan pendukungnya. Hasil penelitian ini juga dimanfaatkan untuk penulisan tugas akhir bagi mahasiswa tingkat S1 Prodi Geofisika, Jurusan Fisika, FMIPA ITS.
[1] Thoha, Achmad Siddik, Karakteristik Citra Satelit (Departemen Kehutanan Fakultas Pertanian, Universitas Sumatra Utara, 2008).

[2] Chander, Gyanesh, Brian L. Markam, and Dennis L. Helder, Journal Remote Sensing of Environment 113, ELSEVIER (2009).

[3] Supriatna, Wahyu, dan Sukartono, Buletin Teknik Pertanian, 7, no. 1, Pusat Penelitian dan Pengembangan Tanah dan Agroklimat, Bogor (2002).

[4] Barsi, Julia A., John L. Barker, John R. Schott, An Atmospheric Correction Parameter Calculator for a Single Thermal Band Earth-Sensing Instrument, IEEE (2003).

[5] Yuan, Fei, and Marvin E. Bauer, Comparison of Impervious Sur- face Area and Normalized Difference Vegetation Index as Indicators of Surface Urban Heat Island Effect in Landsat Imagery, Journal Remote Sensing of Environment, ELSEVIER (2006).

[6] Renaldi, Alvin Agustino, Aplikasi Filter Konvolusi Laplace pada Data Citra Satelit Landsat 7 ETM+ untuk Analisa Kemelurusan (Linement) dalam Pemetaan Bahan Galian Golongan C di Kabupaten Bangkalan, Teknik Fisika ITS, Surabaya (2004).

[7] Sukristiyanti dan Marganingrum, Pendeteksian Kerapatan Vegetasi dan Suhu Permukaan Menggunakan Citra Landsat, Studi Kasus : Jawa Barat Bagian Selatan dan Sekitarnya, Jurnal Riset dan Pertambangan Jilid 19 No.1, LIPI, Bandung (2009). 